УДК: 330:65.012.224:574.63(477)

Колодійчук Ірина, доктор економічних наук, старший науковий співробітник, ДУ «Інститут регіональних досліджень імені М. І. Долішнього НАН Украӥни», старший науковий співробітник відділу регіональної екологічної політики та природокористування, м. Львів; ORCID ID: 0000-0001-5110-3905 e-mail: Ira1166@ukr.net

https://doi.org/10.29038/2786-4618-2021-01-151-160

\title{
ТЕХНІКО-ЕКОНОМІЧНЕ ОБГРУНТУВАННЯ РЕЦИКЛІНГУ ВІДХОДІВ В УКРАЇНІ
}

Проведено аналіз існуючих в Україні технологій перероблення побутових. Наголошено на наявності низки проблем щодо їхньої функціональності. Акцентовано увагу на наявності потужних сировинних ресурсів для впровадження рециклінгу. Виділено основні проблеми місць видалення відходів: відсутність їхньої паспортизації через невідповідність чинним стандартам і продовження нагромадження відходів всупереч вичерпанню термінів експлуатації; вольових рішень щодо закриття техногенно ризикових полігонів; пошуку альтернативних шляхів поводження 3 відходами. Здійснено порівняльну еколого-економічну оцінку технологій перероблення відходів. Зазначено, що актуальним для розвитку системи управління відходами $\epsilon$ використання інноваційних технологій спалювання відходів через реконструкцію та оснащення переробних підприємств сучасними системами горіння і фільтрації відпрацьованих газів для зведення до мінімуму екологічних ризиків. Визначено найефективніший напрям інноваційного оновлення - розвиток потужностей на основі технології стерилізації відходів в автоклавах та сортування ТПВ для рециклінгу.

Ключові слова: рециклінг, спалювання, механіко-біологічне оброблення, місця видалення відходів, утилізація, автоклавний метод перероблення відходів.

Колодийчук Ирина, доктор экономических наук, старший научный сотрудник, старший научный сотрудник отдела региональной экологической политики и природопользования, ГУ «Институт региональных исследований имени М. И. Долишнего НАН Украины», г. Львов

\section{ТЕХНИКО-ЭКОНОМИЧЕСКОЕ ОБОСНОВАНИЕ РЕЦИКЛИНГА ОТХОДОВ В УКРАИНЕ}

Проведен анализ существующих в Украине технологий переработки бытовых отходов. Отмечено наличие ряда проблем по их функциональности. Акцентировано внимание на наличии мощных сырьевых ресурсов для внедрения рециклинга. Выделены основные проблемы мест удаления отходов: отсутствие их паспортизации из-за несоответствия действующим стандартам и продолжение накопления отходов вопреки истечению сроков эксплуатации; волевых решений по закрытию техногенно рисковых полигонов; поиска альтернативных путей обращения с отходами. Осуществлена сравнительная эколого-экономическую оценку технологий переработки отходов. Отмечено, что актуальным для развития системы управления отходами является использование инновационных технологий сжигания отходов путем реконструкции и оснащения перерабатывающих предприятий современными системами горения и фильтрации отработанных газов для сведения к минимуму экологических рисков. Определены эффективное направления инновационного обновления - развитие мощностей на основе технологии стерилизации отходов в автоклавах и сортировки ТБО для рециклинга.

Ключевые слова: рециклинг, сжигание, механико-биологическая обработка, места удаления отходов, утилизация, автоклавный метод переработки отходов.

Kolodiichuk Irina, D.Sc. (Economics), senior researcher of regional environmental policy and environmental management department, 


\section{TECHNICAL AND ECONOMIC RATIONALE FOR WASTE RECYCLING IN UKRAINE}

Introduction. In Ukraine, the most common methods of waste management are active processing - incineration, utilization (mechanical and biological treatment), and passive storage of their inert residues in specially designated areas. According to European standards, these technologies to some extent carry environmental risks and do not belong to full-fledged recycling. Significant volumes of accumulated and generated waste determine the regional economic potential that can be used for the introduction of recycling technologies. The purpose of the article. The purpose of the article is the feasibility study of waste processing in Ukraine given the regional potential for the development of recycling technologies. To achieve this goal, the following tasks were solved: to analyze the existing technologies for processing household and similar waste and to carry out their economic evaluation; identify areas for innovative development of regional waste management systems in the near future. Results. The analysis of existing in Ukraine technologies of processing of household and similar wastes is carried out. It is emphasized that there are a number of problems with their functionality. Emphasis is placed on the availability of powerful raw materials for the implementation of recycling. The main problems of waste disposal sites are highlighted: lack of their certification due to non-compliance with current standards and continued accumulation of waste despite the exhaustion of service life; voluntary decisions to close technogenic risk landfills; finding alternative ways of waste management. A comparative ecological and economic assessment of waste processing technologies has been carried out. Conclusions. Relevant for the development of waste management system is the use of innovative technologies of waste incineration through reconstruction and equipping of processing plants with modern combustion and filtration systems of exhaust gases to minimize environmental risks.

Key words: foreign economic activity, agricultural enterprise, agro-industrial complex, export, import, foreign trade balance.

Постановка проблеми та іï значення. Значні обсяги накопичених та утворених відходів в Україні визначають регіональний економічний потенціал, що може бути задіяний для впровадження рециклінгових технологій. У поводженні 3 відходами найпоширенішими способами $є$ активне перероблення - спалювання, утилізація (механіко-біологічне оброблення), і пасивне зберігання їхніх інертних залишків у спеціально відведених місцях. Згідно з європейськими нормами усі ці технології в тій чи іншій мірі несуть екологічні ризики і не відносяться до повноцінного рециклінгу.

Структура утилізаційних потужностей у вітчизняній системі поводження 3 відходами за кількісними i якісними параметрами не відповідає європейським стандартам, оскільки використовуються застарілі малоефективні технології, що самі по собі становлять екологічну небезпеку. Абсолютна більшість об'єктів поводження з відходами в Україні - це місия видалення відходів (MBВ). Якщо в країнах СС захоронення відходів коштує дорого і вартість однієї тонни може становити від 4 до 75 євро, то в Україні - 0,14 євро, що не сприяє розвитку утилізаційних потужностей і покращанню екологічної ситуації. Станом на 2018 рік, в країні налічувалось 256 перевантажених полігонів, а 1347 звалищ не відповідали нормам екологічної безпеки [1]. Відтермінування паспортизації МВВ протягом усіх років незалежності України спричинює критичний стан їхньої експлуатації та катастрофічно низькі темпи рекультивації закритих полігонів/звалищ. Втім впровадження утилізаційних потужностей активного типу дасть змогу вирішити низку проблем не лише екологічного, а й соціально-економічного характеру, підвищити рівень конкурентоспроможності і якості життя у регіонах України.

Аналіз останніх досліджень і публікацій. Різні аспекти окресленої проблематики стали предметом наукових досліджень українських і зарубіжних учених. Зокрема, теоретико-методологічні засади формування системи управління відходами відображено у працях Н. Бокена [2], Г. Виговської [3], П. Джізелліні [4], Н. Міллара [5], В. Міщенка [6], Р. Мюррея [7], В. Хааса [8] та ін.

Науково-практичні проблеми генерування різних видів відходів і можливостей їхнього подальшого корисного використання на регіональному рівні досліджували такі вчені, як Р. Берлінг [9], О. Горобець [10], Т. Довга [11], О. Ігнатенко [12], О. Руденко [13], М. Самойлік [14], А. Сиволап [15], Н. Хижнякова [16] та ін. Проте ці дослідження загалом стосуються окремих аспектів управління 
відходами. Питанню комплексної оцінки переробки відходів в Україні та формуванню утилізаційних потужностей на основі рециклінгу не приділено належної уваги.

Мета і завдання статті. Метою статті $\epsilon$ техніко-економічне обгрунтування переробки відходів в Україні з огляду на регіональний потенціал розвитку рециклінгових технологій.

Для досягнення поставленої мети вирішувались наступні завдання: проаналізувати існуючі технології перероблення побутових і подібних відходів (ППВ) та здійснити їхню економічну оцінку; визначити напрями інноваційного розвитку регіональних систем управління відходами на найближчу перспективу.

Викладення основного матеріалу та обгрунтування отриманих результатів дослідження.

Поводження 3 відходами у місцях їхнього пасивного зберігання регламентують Правила експлуатації полігонів побутових відходів, затверджені Наказом Міністерства житловокомунального господарства України № 435 від 01.12.2010 р. (зі змінами №134 від 12.05.2014р.) [17].

Технологія поводження 3 ППВ передбачає їхнє перевезення на полігон спеціалізованим автомобільним транспортом, який перед розвантаженням в обов'язковому порядку на ваговій проходить зважування та перевірку на радіологічну безпеку. Розвантажені відходи на робочій карті розрівнюють бульдозерами та ущільнюють спеціальними компакторами у певні шари, які періодично пересипають інертним грунтом. Під час анаеробного розкладання органічної частини відходів утворюються фільтрат та біогаз. Фільтрат просочується крізь шари грунту та відходів в нижню частину карти й потрапляє в дренажну систему, після чого відпомповується в очисні споруди. До 80 \% фільтрату очищується до стану чистої води, яка потрапляє у навколишнє середовище, а приблизно $20 \%$ неочищеного концентрату відводиться у спеціальний відстійник. Утворений біогаз, що є поновлюваним і дешевим джерелом енергії, можна використовувати як місцеве паливо або у спеціальних установках - для виробництва електроенергії.

Біогаз, або так званий звалищний газ, містить до 60 \% метану. У середньому при розкладанні 1 т ППВ може утворюватися 100-200 м³ біогазу з теплотворною здатністю приблизно удвічі нижчою,

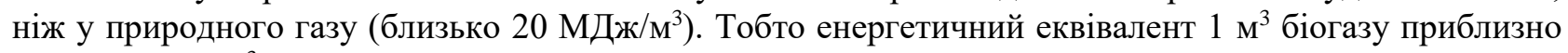
дорівнює $0,5 \mathrm{~m}^{3}$ природного газу, а отже, енергетичний потенціал полігону з розміщенням 1 млн т ТПВ вологістю $40 \%$ еквівалентний 50-60 млн м³ природного газу. Проте, на відміну від природного родовища, на полігонах відсутня газонепроникна ізоляція, що вимагає одночасно з генерацією газу оперативно його видобувати, в іншому разі біогаз викидатиметься в атмосферу. Закономірне поповнення відходів дає змогу використовувати тривалий час це енергетичне джерело. Навіть після закриття полігону ППВ розкладаються ще протягом 20 років, а активне утворення біогазу починається приблизно з третього року від початку зберігання, поступово збільшуючи інтенсивність газоутворення протягом наступних 10-15 років, після чого процес сповільнюється. Тому за середнього виходу «звалищного» газу 100 м³/т ППВ середня швидкість його виходу приймається 5 $\mathrm{м}^{3 / \mathrm{T}}$ ППВ на рік [18].

Утворений на полігонах біогаз інтенсивно видобувають у багатьох країнах світу ще 3 початку 80-х pp. XX ст. На теперішній час світовими лідерами за обсягами річного газовидобутку з полігонів ППВ $є$ : США - 500 млн м³ обсяг видобутку «звалищного» газу становить близько 1,2 млрд м³ на рік, що еквівалентно 429 тис. т метану, або $1 \%$ його світової емісії [18].

Біогаз добувають не лише безпосередньо на полігонах побутових відходів, а й на заводах механіко-біологічної переробки ТПВ. Генерують електроенергію і тепло під час безпосереднього спалювання відходів. У разі видобутку електроенергії з біогазу та біомаси ії можна реалізовувати за «зеленим» тарифом - 0,1239 євро/кВт год. без ПДВ.

За даними Міністерства розвитку громад та територій України, після прийняття у 2015 році Закону України «Про внесення змін до деяких законів України щодо забезпечення конкурентних умов виробництва електроенергії $з$ альтернативних джерел енергії», яким було збільшено «зелений» тариф для електроенергії, що виробляється з біомаси та біогазу з побутових відходів, в Україні спостерігається тенденція до збільшення кількості полігонів, на яких влаштовані системи добування біогазу і встановлені когенераційні установки для вироблення теплової або електричної енергії. Так, на 32 полігонах влаштовано систему добування біогазу і експлуатуються когенераційні установки 
потужністю 19 МВт, а кількість виробленої електроенергії за 2018 рік становила понад 63,3 млн кВт год.

Проблема багатьох полігонів в Україні полягає в їхній експлуатації понад запроєктовані терміни, а також недотриманні норм щодо структури й нормативних обсягів надходження відходів. Через певний період часу полігон вичерпує свій ресурс і не може приймати відходи без негативних наслідків для навколишнього природного середовища. Основними проблемами подальшої його експлуатації є неприємні запахи та фільтрат, а також виникнення аварійних схилів і розширення площі полігону за межі робочих карт. Водночас перевантажені полігони здійснюють прямий вплив на грунти, атмосферне повітря, поверхневі (через забруднення важкими металами - іонами свинцю, нікелю, марганцю) і підземні (через забруднення хромом) води. Досить часто рівень фільтратних озер перевищує рівень існуючих дамб, що підвищує ризики техногенних катастроф і вимагає значних фінансових витрат на укріплення дамб.

Отож, після вичерпання ресурсу полігону його необхідно закривати й вдаватися до рекультивації, проте заходи такого типу проводяться неналежним чином. Коли полігон працює, відповідальні органи влади воліють не задумуватися над стратегічними питаннями поводження 3 відходами, адже одномоментно вирішити проблему утилізації ППВ після закриття полігону неможливо. Цьому передує тривала й витратна робота щодо пошуку місць створення нових полігонів чи будівництва утилізаційних підприємств, організації громадських обговорень, вибору технологій утилізації відходів, організації конкурсних процедур пошуку інвесторів тощо. На жаль, практика свідчить, що поки не виникають техногенні катастрофи або не активізується громадськість у спротиві щодо подальшої експлуатації полігонів, ці об'єкти продовжують приймати відходи, порушуючи законодавчо-регулятивні норми.

Першочерговим завданням у регіональних системах управління відходами є прийняття вольових рішень щодо закриття техногенно ризикових полігонів, що дасть змогу уникнути подальшого погіршення ситуації. Звичайно, цьому передує пошук альтернативних шляхів поводження 3 відходами.

До активних способів перероблення відходів відносимо їхнє спалювання, механіко-біологічне перероблення та сортування.

Основною перевагою спалювання відходів є зменшення їхнього об’єму та нейтралізація запахів від розкладу органічних решток. В Україні у 2018 році кількість установок для спалювання відходів становила 719 одиниць, з яких 576 (10,4 \% від загальної кількості установок для поводження 3 відходами, а також спеціально відведених місць та об’єктів видалення відходів) - для спалювання відходів 3 метою отримання електричної енергії $(R l)$ та 143 - для спалювання 3 метою теплового перероблення відходів (D10). Шляхом використання сумарної потужності у 2018 році було спалено 1028,6 тис. т відходів, 3 них I-III класу небезпеки - 11,9 тис. т, ППВ - 206,5 тис. т.

Діяльність, пов'язана зі спалюванням відходів з метою отримання енергії $(R l)$, належить до операцій утилізації, однак спалювання твердих побутових відходів (ТПВ) не сприяє ефективному виробленню енергії, позаяк більшість із них - вологі і не всі горючі. Водночас під час спалювання знищуються всі сировинні ресурси для можливого подальшого рециклінгу.

На теперішній день в регіонах України спалюється лише 3 \% побутових відходів, а Стратегія [19] регламентує, що це значення не повинно перевищувати 10 відсотків. Утім будівництво сміттєспалювальних заводів для інвесторів є мало привабливим, оскільки залежно від потужності воно обійдеться у 130-270 млн євро 3 дотриманням усіх екологічних норм, а собівартість перероблення при цьому досить висока. Крім того, на генеровану сміттеспалювальними заводами енергію «зелений» тариф не поширюється і після поверхневого сортування дешевше відходи відправити на полігони, ніж спалювати. Наприклад, київський завод «Енергія», який переробляє 280 тисяч т ТПВ на рік і забезпечує опаленням близько 300 будинків житлового масиву Позняки, за спалювання тонни ТПВ отримує 143,5 грн, тоді як тариф на захоронення становить у середньому від 50 до 110 грн.

Значним бар'єром у використанні сміттєспалювальних установок є спротив місцевого населення 3 огляду на забруднення повітря шкідливими викидами та засмічення грунтів залишками продуктів горіння (золи). Проте інноваційні технології спалювання відходів за рахунок сучасних систем горіння та фільтрації відпрацьованих газів знижують екологічний ризик до мінімуму. До прикладу, у 
Швейцарії від спалювання однісї тонни ППВ на сучасному заводі з інноваційними фільтрувальними установками забруднення еквівалентне спалюванню 1 кг змішаних відходів просто неба. Однак, на наш погляд, спалювання відходів все ж не є стратегічним пріоритетом для України і в перспективі необхідно забезпечити заміну сміттєспалювальних потужностей іншими, екологічно безпечнішими технологіями перероблення.

Складовою утилізації є сортування відходів на спеціальних комплексах, але ефективність цього процесу досягається лише за умови їхнього попереднього сортування у місцях утворення. Це дає змогу збирати сухі відходи і здійснювати ефективніше їхнє перероблення, але вимагає встановлення відповідних місткостей для роздільного збирання та проводити відповідну роз'яснювальну роботу 3 населенням. За дотримання зазначених вимог сміттєсортувальні комплекси можуть досягти $20 \%$ рециклінгу від маси ППВ.

Перевантаження МВВ в регіонах Україні вимагає використання технологій перероблення, що зменшують фізичні обсяги захоронення ППВ до мінімуму. Морфологічна структура відходів свідчить про високий вміст органічних домішок. Для ефективної нейтралізації органічної фракції, яка може сягати до 70 \% від загальної кількості ППВ, найбільш прийнятним для України буде механіко-біологічне перероблення відходів, яке передбачає операції компостування, а також аеробне $\mathrm{i} /$ або анаеробне перероблення органічних відходів. Механіко-біологічне перероблення побутових відходів дає змогу відокремити ресурсно-ціннісну фракцію (пластик, папір, скло, метали та ін.), а органічну фракцію стабілізувати до інертної з можливістю виділення біогазу для виробництва електроенергії. Органічна фракція потрапляє до потужностей компостування або стабілізаційних тунелів, які їі висушують, після чого органіка вже не є шкідливою з точки зору фільтратів та біогазу, суттєво зменшується в об'ємі.

Згідно 3 дослідженням Біоенергетичної асоціації України (www.uabio.org) завод 3 механікобіологічною технологією може заробляти за «зеленим» тарифом 29,7 євро за тонну перероблених ТПВ. Однак інвестиційна привабливість будівництва таких об'єктів за чинного законодавства зменшуватиметься, позаяк передбачається поступове зниження рівня «зеленого» тарифу - на $10 \%$ у 2020 і 2025 роках, до кінцевого припинення дії у 2030 році.

Недоліком механіко-біологічної технології є значна емісія неприємних запахів, що вимагає віддаленого розташування переробних підприємств від населених пунктів. Низька культура роздільного збору відходів населенням в Україні вимагає додаткового ручного сортування перед їхнім потраплянням на лінії та сортувальні барабани.

Аналіз системи поводження з відходами в Україні засвідчив, що процес утилізації обмежується їхнім механіко-біологічним переробленням та сортуванням, що не відноситься до повноцінного рециклінгу, а утилізаційні заходи у промислових регіонах загалом пов'язані зі зворотною засипкою відходів добувної промисловості і розроблення кар'єрів, що не належить до операцій перероблення відходів.

На відвалах промислових підприємств України накопичилося близько 250 млн т вугільних і 100 млн т металургійних шлаків і щороку ця цифра зростає. Загалом Україна використовує приблизно удвічі менше шлаків, ніж інші країни світу. У 2018 році підприємства країни відправили на утилізацію лише 4,9 млн т шлаків, або 45,5\%. При цьому 2,1 млн т використано для виробництва цементу, а 1 млн т - на дорожнє будівництво.

Останнім часом спостерігається позитивна тенденція щодо використання відходів металургії. Зокрема, розпорядженням Кабінету Міністрів України № 1420-р від 4 грудня 2019 року «Про використання відходів виробництва в дорожньому будівництві» [20] уряд рекомендує Державному агентству автомобільних доріг, обласним і Київській міській державним адміністраціям під час закупівлі послуг з ремонту автодоріг обов'язково передбачати застосування металургійних шлаків. За оцінкою GMK Center [21], Україна може збільшити використання шлаків у дорожньому будівництві як мінімум уп'ятеро. В Україні налічується близько 430 тис. км доріг. Якщо щорічно ремонтувати хоча 63 тис. км (близько 0,6 \% від їхньої кількості), то споживання шлаків збільшиться щонайменше до 5 млн т - це в п'ять разів більше, ніж сьогодні.

Існуючі технології перероблення відходів не забезпечують достатній рівень екологічної безпеки, що вимагає пошуку альтернативних технологій. Серед сучасних утилізаційних систем заслуговує на увагу автоклавний метод перероблення змішаних відходів, що поєднує високу економічну ефектив- 
ність та екологічність. На ринку виробництва технологічного обладнання для перероблення відходів помітне місце займає польська компанія Bioelektra Group S.A. Інженерна група Bioelektra вдало поєднала автоклавний метод (метод стерилізації) із системою автоматизованого сортування відходів, що в кінцевому результаті забезпечує $65 \%$ рециклінгу ППВ. Суттєвою перевагою автоклавного методу $є$ відсутність емісії запахів і можливість будівництва переробного підприємства поряд із населеними пунктами, що суттєво знижує транспортно-логістичні витрати. Технологія також не потребує попереднього сортування відходів у місцях їхнього утворення, що $є$ актуальним питанням у вітчизняних умовах.

Стерилізація в автоклавах проходить за температури $125-140^{\circ} \mathrm{C}$ і тиском до 3 бар протягом трьох годин, що забезпечує до 60 \% зменшення об’єму відходів та приблизно на 17 \% їхньої маси за рахунок випаровування вологи. Змішані стерилізовані відходи передаються на систему розподілу механічну, оптичну, повітряну і магнітну. Усі фракції при цьому залишаються стерильними для подальшого перероблення (рециклінгу) (табл. 1).

Таблиия 1

\section{Фракційний склад ресурсної складової для подальшого перероблення і рециклінгу автоклавного методу*}

\begin{tabular}{|c|c|c|}
\hline Pecypc & Характеристика & Застосування \\
\hline 1 & 2 & 3 \\
\hline Біомаса & $\begin{array}{l}\text { - складається загалом } \\
\text { біодеградуючих відходів, включаючи папір, } \\
\text { стерильна і без запаху; } \\
\text { - однорідний фізичний продукт, незалежно від } \\
\text { структури відходів; } \\
\text { - низькі рівні концентрації важких металів, } \\
\text { сірки та хлорки; } \\
\text { - тепловий коефіцієнт: } 12 \text { ГДЖ/ т; } \\
\text { - вихід метану: } 110 \text { м³/т; } \\
\text { - до } 15 \% \text { домішок (в основному мінеральних). }\end{array}$ & $\begin{array}{l}\text { - } \text { паливо для тепло- і електростанцій; } \\
\text { - } \text { паливо для піролізу; } \\
\text { - процеси анаеробного зброджування; } \\
\text { - поліпшення грунту як органічне } \\
\text { добриво; } \\
\text { - засіб для виробництва будівельних } \\
\text { матеріалів: } 10 \% \text { в цеглу, } 50 \% \text { як } \\
\text { легкий наповнювач. }\end{array}$ \\
\hline Метал & $\begin{array}{l}\text { - відділяється понад } 95 \text { \% алюмінію і чорних } \\
\text { металів; } \\
\text { - сухі органічні залишкові матеріали в } \\
\text { бляшанках не впливають на подальше } \\
\text { перероблення; } \\
\text { - повне видалення ярликів і фарби. }\end{array}$ & $\begin{array}{l}\text { - } \text { виробництво алюмінію; } \\
\text { - } \text { виробництво сталі. }\end{array}$ \\
\hline Скло & $\begin{array}{l}\text { - відділяється понад } 97 \text { \% скла; } \\
\text { - максимально до } 5 \text { \% домішок; } \\
\text { - повне видалення ярликів, фарби та інших } \\
\text { сторонніх матеріалів. }\end{array}$ & $\begin{array}{l}\text { - } \quad \text { виробництво пакувальної продукції; } \\
\text { - } \quad \text { виробництво } \\
\text { (утеплювача); } \\
\text { - } \quad \text { виробництво піноскла. } \\
\end{array}$ \\
\hline Пластмаса & $\begin{array}{l}\text { - відділяється понад } 90 \text { \% пластмаси; } \\
\text { - залежно від структури, з поділом на будь-який } \\
\text { з таких видів пластмаси: поліетилентерефталат } \\
\text { (ПЕТ), поліетилен, полістирол, полівінілхлорид; } \\
\text { - сухі органічні залишкові матеріали в пляшках } \\
\text { не впливають на подальше перероблення; } \\
\text { - повне видалення ярликів і фарби, однорідна за } \\
\text { складом сировина. }\end{array}$ & $\begin{array}{l}\text { - виробництво гранул } \\
\text { пакувальної, текстильної та іншої } \\
\text { промисловості; } \\
\text { - виробництво мастила для дизельних } \\
\text { двигунів; } \\
\text { - композитне виробництво. }\end{array}$ \\
\hline $\begin{array}{c}\text { Папір } \\
\text { (целюлоза) }\end{array}$ & $\begin{array}{l}\text { - } 30-50 \text { \% паперу виділяються загалом із } \\
\text { багатошарової упаковки, типу Тетра-пак; } \\
\text { - велика частина паперу переробляється на } \\
\text { біомасу; } \\
\text { - низький рівень мінеральних залишків не } \\
\text { впливає на подальше перероблення; }\end{array}$ & $\begin{array}{l}\text { - виділення целюлози для } \\
\text { виробництва упаковки } \\
\text { на папаперових фабриках. }\end{array}$ \\
\hline
\end{tabular}




$$
\text { - не залишається фарби і забруднень. }
$$

*Джерело: складено на основі комерційної пропозиції Bioelektra Group S.A.

Програма автоматично аналізує структуру відходів і відповідно обробляє їх, забезпечуючи сортування понад 90 \% вторинної сировини (пластику, металу, скла). При цьому також відбувається очищення пластику, скла і металів від ярликів, фарби, органічних решток, а матеріали стають однорідними за типом і складом та позбуваються неприємних запахів. На відміну від інших систем, доходи від продажу ресурсів покривають усі інвестиційні та експлуатаційні витрати, оскільки лише 4 \% відходів вивозиться на звалище, а все інше - це біомаса, паливо RDF (Refuse Derived Fuel), метал, скло і пластик. При цьому біомаса може використовуватися як паливо для тепло- і електростанцій, піролізних установок, а також як органічне добриво, компонент для виробництва будівельних матеріалів тощо.

Порівняльна характеристика витрат на використання розглянутих технологій представлена в табл. 2, що свідчить про високу конкурентоспроможність автоклавного методу, який, зокрема, пропонує компанія Bioelektra Group S.A. Найвитратнішою є технологія спалювання відходів, але це пов'язано зі жорсткими європейськими нормами щодо емісії відпрацьованих газів та значними витратами на встановлення й експлуатацію фільтрувальних установок. Широкий діапазон витрат на утилізацію відходів спричинений різноманітністю й складністю наявних технологій - від процесу простого сортування до систем анаеробного зброджування.

Отже, порівняльна еколого-економічна оцінка наявних в Україні технологій перероблення відходів свідчить, що:

- спалювання ППВ з метою отримання енергії $(R l)$ неефективне через низьку горючість вологих відходів та залишок великої маси золи і абсорбентів, а також знищення всіх сировинних ресурсів, за винятком частини металів, для подальшого рециклінгу;

- сортувальні комплекси вимагають роздільного надходження відходів та забезпечують низький рівень (20\%) відсортованих відходів для рециклінгу;

- механіко-біологічне перероблення відходів ефективно нейтралізує органічну фракцію, зменшуючи фізичні обсяги захоронення ППВ, але значна емісія неприємних запахів вимагає віддаленого розташування переробних підприємств від населених пунктів, а низька культура роздільного збору відходів в Україні вимагає додаткового ручного їхнього сортування;

- автоклавний метод перероблення змішаних відходів забезпечує високу економічну ефективність та екологічність за рахунок 65 \% автоматично відсортованих ППВ для рециклінгу, відсутність емісії запахів та можливість будівництва переробних підприємств поряд із населеними пунктами, що суттєво знижує логістичні витрати.

Таблиця 2

\section{Порівняльна характеристика витрат на використання технологій перероблення відходів*}

\begin{tabular}{|l|c|c|c|}
\hline \multicolumn{1}{|c|}{ Вид витрат } & Спалювання & $\begin{array}{c}\text { Утилізація (механіко- } \\
\text { біологічне } \\
\text { перероблення / } \\
\text { сміттєсортувальні } \\
\text { комплекси) }\end{array}$ & $\begin{array}{c}\text { Автоклавний } \\
\text { метод (Bioelektra } \\
\text { Group S.A.) }\end{array}$ \\
\hline $\begin{array}{l}\text { Капіталовкладення, Свро/т } \\
\text { річної продуктивності }\end{array}$ & $700-1000$ & $150-450$ & $300-400$ \\
\hline $\begin{array}{l}\text { Експлуатаційні витрати, } \\
\text { Євро/т }\end{array}$ & $80-120$ & $20-70$ & 25 \\
\hline
\end{tabular}

*Джерело: підготовлено на основі (www.bioelektra.pl).

Прагнення до економічного зростання без належної уваги до розвитку утилізаційних потужностей призведе до положення цугцванга соціально-економічного розвитку територій. Варіативність рішень проблеми передбачає або згортання економічної активності підприємств, або введення в експлуатацію нових утилізаційних потужностей традиційного типу. Неприпустимість першого й витратність другого шляху вимагають концентрації зусиль на формуванні нової якості у 
системі поводження 3 відходами - задіяння мало- та безвідходних технологій виробництва 3 використанням рециклінгових систем управління відходами. Хоча ці технології ще досить вартісні й малодоступні для національної економіки, їхнє впровадження є виправданим і перспективним.

\section{Висновки і перспективи подальших досліджень.}

Отож, стратегічним орієнтиром для України щодо управління відходами є використання регіонального економічного потенціалу накопичених та утворених відходів для впровадження рециклінгових технологій, і потужним сировинним джерелом для цього є наявні місця видалення відходів. Це також підтверджує досвід розвинутих європейських країн, в яких менше 5 \% відходів потрапляє на полігони проти 93 \% в Україні. Інноваційний розвиток регіональної системи управління відходами вбачаємо:

- у використанні регіонального економічного потенціалу накопичених та утворених відходів для впровадження рециклінгових технологій;

- у використанні інноваційних технологій спалювання відходів за рахунок реконструкції та обладнання переробних підприємств сучасними системами горіння та фільтрації відпрацьованих газів для зведення до мінімуму екологічних ризиків;

- у розвитку потужностей на основі інноваційної технології стерилізації відходів в автоклавах та сортування ТПВ для рециклінгу, що є найбільш прийнятною для умов України за критеріями економічної ефективності та екологічності.

\section{Джерела та література}

1. Стан сфери поводження з побутовими відходами в Україні за 2018 рік: інформація Міністерства розвитку громад та територій України. URL: http://www.minregion.gov.ua/napryamkidiyalnosti/zhkh/terretory/stan-sferi-povodzhennya-z-pobutovimi-vidhodami-v-ukrayini-za-2018-rik/.

2. Geissdoerfer M., Savaget P., Bocken N., Hultink E. The circular economy - a new sustainability paradigm. Journal of Cleaner Production. 2017. Vol. 143, № $1 . \quad$ P. $757-768$. URL : https://www.sciencedirect.com/science/article/pii/S0959652616321023?via\%3Dihub .

3. Виговська Г. П. Концептуальні засади створення нормативно-правової та методичної бази у сфері поводження з відходами. Утилизация отходов. Организация и контроль полигонов: сб. научн. ст. Одеса : ОЦНТЭИ, 1999. С. 16-34.

4. Ghisellini P., Cialani C., Ulgiati S. A reviewon circular economy: the expected transition ta balanced interplay of environmental and economic systems. Journal of Cleaner Production. 2016. Vol. 114, № 2. P. 11. URL : https://doi.org/10.1016/j.jclepro.2015.09.007 .

5. Millar N., McLaughlin E., Boerger T. The circular economy: swings and roundabouts. Ecological Economics. 2019. Vol. 158, № 4. P. 11-19. URL : https://doi.org/10.1016/j.ecolecon.2018.12.012 .

6. Міщенко В. С. Удосконалення системи класифікації відходів і засади українського LIST OF WASTES. Экология и промышленность. 2011. № 2. С. 107-111.

7. Мюррей Р. Цель - Zero Waste. Москва : ОМННО «Совет Гринпис», 2004. 232 с.

8. Haas, W., Krausmann, F., Wiedenhofer, D., Heinz M. (2015). How circular is the global economy? Journal of Industrial Ecology, 5, 765-777. Vol. 19. Available at: https://onlinelibrary.wiley.com/doi/epdf/10.1111/jiec.12244

9. Берлінг Р. 3., Данилович Т. Б. Проблеми функціонування системи управління відходами в Україні і шляхи їі вдосконалення. Вісник Нац. ун-ту «Львів. політехніка». 2006. № 552. С. 344-349.

10. Горобець О. В. Напрями удосконалення управління поводженням з відходами в Україні. Економіка. Управління. Інновації. 2013. № 1. URL: http://nbuv.gov-.ua/-UJRN/-eui_2013_1_16 .

11. Довга Т. М. Основні тенденції та закономірності утворення і переробки твердих побутових відходів в Україні. Ефективна економіка. 2012. № 10. URL: http://www.economy.nayka.com.ua/?op=1\&z=1491 .

12. Ігнатенко О. П. Інвестиційне значення побутових відходів у сфері благоустрою населених пунктів. Інвестииіï: практика та досвід: наук.-практ. журн. Київ : ДКС Центр, 2014. № 11. С. 139-143.

13. Руденко О. В. Відходи гірничо-збагачувального виробництва: особливості при визнанні їх об'єктом обліку. Свропейський вектор економічного розвитку. 2011. № 1 (10). С. 202-207.

14. Самойлік М. С. Економічна модель розвитку сфери поводження з твердими відходами регіону 3 урахуванням екологічних факторів. Вісник Полтавської державної аграрної академії. 2014. № 1. С. 82-87.

15. Сиволап А. В. Регулирование потока ТБО. Экономика и управление. 2005. № 4-5. С. 99-104.

16. Хижнякова Н. О. Обгрунтування проектів комплексного перероблення побутових відходів. Вісник Національного ун-ту «Львівська політехніка»: Логістика. 2003. № 472. С. 522-526. 
17. Правила експлуатації полігонів побутових відходів: Наказ Міністерства житлово-комунального господарства України. № 435 від 01.12.2010 р. (зі змінами № 134 від 12.05.2014 р.). Офіиійний вісник Украӥни. 2010. № 100. С. 238.

18. Сміттєвий» газ - модно у світі, перспективно для України. URL: http://ua.tiseco.com.ua/index.php?option= $=$ com_content\&task=view\&id= $\neg 186$ \&Itemid=19 .

19. Про схвалення Національної стратегії управління відходами в Україні до 2030 року: Розпорядження Кабінету Міністрів України № 820-р від 8 листопада 2017 р. Офіиійний вісник Украӥни. 2017. № 94. С. 61.

20.Про застосування відходів виробництва в дорожньому будівництві : Розпорядження Кабінету Міністрів України № 1420-р від 4 грудня 2019 р. Урядовий кур’єр. № 32.

21. Кабмін рекомендує збільшити застосування шлаків у будівництві доріг. URL: https://gmk.center/ua/news/kabmin-rekomenduie-zbilshiti-zastosuvannya-shlakiv-u-budivnictvi-dorig/) (дата звернення: 19.02.2020).

\section{References}

1. Stan sfery povodzhennia $\mathrm{z}$ pobutovymy vidkhodamy v Ukraini za 2018 rik: informatsiia Ministerstva rozvytku hromad ta terytorii Ukrainy. URL: http://www.minregion.gov.ua/napryamki-diyalnosti/zhkh/terretory/stansferi-povodzhennya-z-pobutovimi-vidhodami-v-ukrayini-za-2018-rik/ . [in Ukrainian].

2. Geissdoerfer M., Savaget P., Bocken N., Hultink E. (2017). The circular economy - a new sustainability paradigm. Journal of Cleaner Production. Vol. 143, № 1. P. 757-768. URL : https://www.sciencedirect.com/science/article/pii/S0959652616321023?via\%3Dihub . [in English].

3. Vyhovska H. P. (1999). Kontseptualni zasady stvorennia normatyvno-pravovoi ta metodychnoi bazy u sferi povodzhennia z vidkhodamy. [Conceptual bases of creation of normative-legal and methodical base in the field of waste management]. Utylyzatsyia otkhodov. Orhanyzatsyia y kontrol polyhonov: sb. nauchn. st. Odesa : OTsNTЭY. S. 16-34. [in Ukrainian].

4. Ghisellini P., Cialani C., Ulgiati S. (2016). A reviewon circular economy: the expected transition ta balanced interplay of environmental and economic systems. Journal of Cleaner Production. Vol. 114, № 2. P. 11. URL : https://doi.org/10.1016/j.jclepro.2015.09.007 . [in English].

5. Millar N., McLaughlin E., Boerger T. (2019) The circular economy: swings and roundabouts. Ecological Economics. Vol. 158, № 4. P. 11-19. URL : https://doi.org/10.1016/j.ecolecon.2018.12.012 .

6. Mishchenko V. S. (2011). Udoskonalennia systemy klasyfikatsii vidkhodiv i zasady ukrainskoho LIST OF WASTES. [Improving the waste classification system and the principles of the Ukrainian LIST OF WASTES]. Эkolohyia y promushlennost. № 2. S. 107-111. [in Ukrainian].

7. Miurrei R. (2004). Tsel - Zero Waste. [Target - Zero Waste]. Moskva: OMNNO «Sovet Hrynpys». 232 s. [in Russian].

8. Haas, W., Krausmann, F., Wiedenhofer, D., Heinz M. (2015). How circular is the global economy? Journal of Industrial Ecology, 5, 765-777. Vol. 19. Available at: https://onlinelibrary.wiley.com/doi/epdf/10.1111/jiec.12244 . [in English].

9. Berlinh R. Z., Danylovych T. B. (2006). Problemy funktsionuvannia systemy upravlinnia vidkhodamy v Ukraini i shliakhy yii vdoskonalennia. [Problems of waste management system functioning in Ukraine and ways of its improvement]. Visnyk Nats. un-tu «Lviv. politekhnika». № 552. S. 344-349. [in Ukrainian].

10. Horobets O. V. (2013). Napriamy udoskonalennia upravlinnia povodzhenniam z vidkhodamy v Ukraini. [Directions for improving waste management in Ukraine]. Ekonomika. Upravlinnia. Innovatsii. № 1. URL: http://nbuv.gov-.ua/-UJRN/-eui_2013_1_16 . [in Ukrainian].

11. Dovha T. M. (2012). Osnovni tendentsii ta zakonomirnosti utvorennia i pererobky tverdykh pobutovykh vidkhodiv v Ukraini. [The main trends and patterns of solid waste generation and processing in Ukraine.]. Efektyvna ekonomika. № 10. URL: http://www.economy.nayka.com.ua/?op=1\&z=1491 . [in Ukrainian].

12. Ihnatenko O. P. (2014). Investytsiine znachennia pobutovykh vidkhodiv u sferi blahoustroiu naselenykh punktiv. [Investment value of household waste in the field of improvement of settlements]. Investytsii: praktyka ta dosvid: nauk.-prakt. zhurn. Kyiv : DKS Tsentr. № 11. S. 139-143. [in Ukrainian].

13. Rudenko O. V. (2011). Vidkhody hirnycho-zbahachuvalnoho vyrobnytstva: osoblyvosti pry vyznanni yikh obiektom obliku. [Mining and processing wastes: peculiarities in their recognition as an object of accounting.]. Yevropeiskyi vektor ekonomichnoho rozvytku. № 1 (10). S. 202-207. [in Ukrainian].

14. Samoilik M. S. (2014). Ekonomichna model rozvytku sfery povodzhennia z tverdymy vidkhodamy rehionu z urakhuvanniam ekolohichnykh faktoriv. [Economic model for the development of solid waste management in the region, taking into account environmental factors]. Visnyk Poltavskoi derzhavnoi ahrarnoi akademii. № 1. S. 82-87. [in Ukrainian]. 
15. Syvolap A. V. (2005). Rehulyrovanye potoka TBO. [Solid waste flow regulation]. Эkonomyka y upravlenye. № 4-5. S. 99-104. [in Russian].

16. Khyzhniakova N. O. (2003). Obgruntuvannia proektiv kompleksnoho pereroblennia pobutovykh vidkhodiv. [Substantiation of projects of complex processing of household waste.]. Visnyk Natsionalnoho un-tu «Lvivska politekhnika»: Lohistyka. № 472. S. 522-526. [in Ukrainian].

17. Pravyla ekspluatatsii polihoniv pobutovykh vidkhodiv: Nakaz Ministerstva zhytlovo-komunalnoho hospodarstva Ukrainy. № 435 vid 01.12.2010 r. (zi zminamy № 134 vid 12.05.2014 r.). [Rules of operation of landfills for household waste: Order of the Ministry of Housing and Communal Services of Ukraine. № 435 dated 01.12.2010]. Ofitsiinyi visnyk Ukrainy. 2010. № 100. S. 238. [in Ukrainian].

18. Smittievyi» haz - modno u sviti, perspektyvno dlia Ukrainy. [Garbage gas is fashionable in the world, promising for Ukraine.]. URL: http://ua.tiseco.com.ua/index.php?option=com_content\&task=view\&id=186 \&Itemid=19. [in Ukrainian].

19. Pro skhvalennia Natsionalnoi stratehii upravlinnia vidkhodamy v Ukraini do 2030 roku: Rozporiadzhennia Kabinetu Ministriv Ukrainy № 820-r vid 8 lystopada 2017 r. [On approval of the National Waste Management Strategy in Ukraine until 2030: Order of the Cabinet of Ministers of Ukraine № 820-r of November 8, 2017]. Ofitsiinyi visnyk Ukrainy. 2017. № 94. S. 61. [in Ukrainian].

20. Pro zastosuvannia vidkhodiv vyrobnytstva $\mathrm{v}$ dorozhnomu budivnytstvi : Rozporiadzhennia Kabinetu Ministriv Ukrainy № 1420-r vid 4 hrudnia 2019 r. [On the use of industrial waste in road construction: Order of the Cabinet of Ministers of Ukraine № 1420-r of December 4, 2019]. Uriadovyi kurier. № 32. [in Ukrainian].

21. Kabmin rekomenduie zbilshyty zastosuvannia shlakiv u budivnytstvi dorih. [The Cabinet of Ministers recommends increasing the use of slag in road construction]. URL: https://gmk.center/ua/news/kabmin-rekomenduiezbilshiti-zastosuvannya-shlakiv-u-budivnictvi-dorig/ . [in Ukrainian]. 